\title{
Chemical composition and antitumor activity of different wild varieties of Moroccan thyme
}

\author{
Abdeslam Jaafari', Hassan Ait Mouse ${ }^{1}$, El Mostapha Rakib', Lahcen Ait M'barek', Mounir \\ Tilaoui $^{1}$, Chouaib Benbakhta ${ }^{3}$, Abdelali Boulli', Aziz Abbad ${ }^{5}$, Abdelmajid Zyad ${ }^{1}$ *
}

${ }^{1}$ Laboratoire d'Immunologie, Biochimie et Biologie Moléculaire, Équipe des Substances Naturelles et Immunopharmacologie Cellulaire et Moléculaire, Faculté des Sciences et Techniques, B.P. 523, Béni-Mellal, Morocco,

${ }^{2}$ Equipe d'Hétérochimie Organique, Département de Chimie et Environnement, Faculté des Sciences et Techniques, B.P. 523, Béni-Mellal, Morocco,

${ }^{3}$ Département de Toxicologie, Institut National d'Hygiène, Av. Ibn Battouta, B.P. 769, Rabat, Morocco, ${ }^{4}$ Laboratoire de Valorisation des Ressources Naturelles, Faculté des Sciences et Techniques, B.P. 523, Béni-Mellal, Morocco, ${ }^{5}$ Laboratoire d'Écologie Végétale, Faculté des Sciences Semlalia, Marrakech, Morocco

\begin{abstract}
RESUMO: "Composição química e atividade antitumoral de diferentes variedades selvagens de tomilho Marroquino". Muitas espécies de Tomilho têm sido amplamente utilizadas na medicina popular morroquina como agentes antiinflamatório, antioxidante e antinociceptivo. Este estudo foi realizado para analisar a composição química e a atividade antitumoral in vitro dos óleos essenciais e de vários extratos de espécies de tomilho coletadas em diferentes regiões do Marrocos. O óleo essencial, obtido através de hidrodestilação, e os vários extratos, obtidos por extração em aparelho de Soxhlet, utilizando solventes de diferentes polaridades, foram analisados através de cromatografia gasosa acoplada à espectrometria de massas (CG/EM). Tanto os componentes majoritários quanto os minoritário foram analisados. De um modo geral, os constituintes principais da composição química das populações de tomilho morroquinas foram carvacrol, timol, borneol e p-cimeno. A quantidade desses componentes pode ser de $85 \%, 42 \%$, $59 \%$, e $23 \%$, respectivamente. Em adição, os óleos essenciais bem como dois produtos puros (carvacrol e timol) foram testados quanto à sua atividade antitumoral contra mastocitoma da linhagem P815. Enquanto todos esses produtos mostraram efeito citotóxico dependente da dose, o carvacrol foi o mais citotóxico quando comparado aos outros. Interessantemente, quando estes produtos foram testados contra células mononucleares sangüíneas periféricas humanas normais, mostraram efeito proliferativo em vez de citotóxico.
\end{abstract}

Unitermos: Thymus, Lamiaceae, CG/EM, composição química, carvacrol, timol, atividade antitumoral.

\begin{abstract}
Many species of Thyme have been widely used in Moroccan folk medicine as anti-inflammatory, antioxidant and antinociceptive agents. This study was designed to examine the chemical composition and the in vitro antitumor activity of the essential oils and various extracts of thyme species collected in different regions of Morocco. The essential oil, obtained by hydrodistillation, and the various extracts, obtained by Soxhlet extraction, using solvents of varying polarity, were analysed by gas chromatography coupled to mass spectrometry (GC-MS). Both major and trace components were analysed. Overall, the major constituents in the chemical composition of Moroccan thyme populations were carvacrol, thymol, borneol and p-cymene. The rate of these components can hit respectively to $85 \%, 42 \%, 59 \%$, and $23 \%$. Furthermore, the essential oils as well as two pure products (carvacrol and thymol) were tested for their antitumoral activity against P815 mastocytoma cell line. While all these products showed a dose dependent cytotoxic effect, the carvacrol was the most cytotoxic one compared to the others. Interestingly, when these products were tested against the normal human peripheral blood mononuclear cells, they show a proliferative effect instead of a cytotoxic one.
\end{abstract}

Keywords: Thymus, Lamiaceae, GC/MS, chemical composition, carvacrol, thymol, antitumor activity. 


\section{INTRODUCTION}

Over the recent years, there has been growing interest in naturally occurring phytochemical compounds with anticancer potential. These products are relatively not toxic, inexpensive and available in an ingestive form. During the two last decades, more than $25 \%$ of drugs used are directly derived from plants, while the other 25 $\%$ are chemically altered natural products (Vuorelaa et al., 2004).

The thyme is an aromatic plant of the Mediterranean flora, commonly used as spices and as traditional medicine remedies. Close to 100 species have been identified in the kind of Thymus across the world (Richard et al., 1985). They are reported to possess some biological effects such as antispasmodic (Meister et al., 1999), antibacterial (Essawi; Srour, 2000 and Dob et al., 2006), antifungal (Soliman; Badeaa, 2002), antitabagism (Carlini et al., 2006), giardicidal (Amaral et al., 2006) and antioxidant activities (Tepe et al., 2005). The First Edition of Brazilian Official Pharmacopoeia, published in 1926, includes 1702 Monographs for medicinal products. Among those, two Monographs refer the thyme (Brandão et al., 2006). In Morocco, the thyme is represented by many species of which certain are endemic. The flowered stem contains essentially flavonoids (derived of apigenol and luteolol), acids phenols (in particular, cafeic and rosmarinic), tannins, resin and especially essential oil rich in chemical compounds which are responsible for the majority of its pharmacological effects (Hmamouchi, 2001). The thyme has been used, in Moroccan traditional medicine, in the treatment of diarrhoea, fever, cough, infected areas and wounds. It was also used as a tonic and stimulant (Bellakhdar, 1996; Sijelmassi, 1993) and, generally, for its anti-inflammatory properties after topical or oral administration (Ismaili et al., 2001; 2002; 2004). Considering the popular use of this plant to relieve some pains, we focused in this report on investigating the chemical composition and the in vitro antitumor activity of the essential oils, as well as various extracts of different thyme species.

\section{MATERIAL AND METHODS}

\section{Plant material}

The species used in our study are the following:

Tm: Thymus maroccanus, was collected at Asni moulay Brahim- Marrakech (high Atlas of Morocco)

Tl: Thymus leptobotris, was collected at Tiznit- (southwest of Morocco)

Tp: Thymus pallidus, was collected at Ourika (high Atlas of Morocco)

Tz: Thymus zygis, was collected at ozoud- Azilal (high Atlas of Morocco)

478 Rev. Bras. Farmacogn.

Braz J. Pharmacogn.

17(4): Out./Dez. 2007
Ts1: Thymus satureoides, was collected at Asni moulay Brahim- Marrakech (high Atlas of Morocco)

Ts2: Thymus satureoides, was collected at bin elwidaneBeni-Mellal (center of Morocco)

Ts3: Thymus satureoides, was collected at Tiznit- (southwest of Morocco)

Tb1: Thymus broussonettii, was collected at AakrachRabat (west of Morocco)

Tb2: Thymus broussonettii, was collected at Essaouira (south-west of Morocco)

Ta1: Thymus algeriensis, was collected at Imizar- Azilal (high Atlas of Morocco)

Ta2: Thymus algeriensis, was collected at Ait AatabAzilal (high Atlas of Morocco)

Thymus satureoides, Thymus broussonettii (endemic species of Morocco) and Thymus algeriensis (endemic of Arab Maghreb) are represented by more than one variety collected in different regions in order to determine the possible intraspecific variation of chemical composition according to the geographical localization. All the samples have been collected in June 2004.

\section{Preparation of the essential oils and extracts}

The Thyme leaves and flowers were dried at $35{ }^{\circ} \mathrm{C}$ and triturated in order to obtain a powder. Then, $250 \mathrm{~mL}$ of solvent was added to this powder $(200 \mathrm{~g})$ to obtain solvent extract using a soxhlet apparatus. The extracts obtained were concentrated until the total evaporation of solvent with a rotary evaporator, and dissolved and made up to have appropriate volume with DMSO (dimethyl sulfoxid) just before the start of the analysis by GC/MS. The essential oils were extracted by hydrodistillation.

\section{Gas chromatography-mass spectrometry}

GC/MS analysis was performed on a THERMO ELECTRON Trace MS system (THERMO ELECTRON: Trace GC Ultra; Poalris Q MS) equipped with DB-5 capillary column $(30 \mathrm{~m} 0.25 \mathrm{~mm}$; film thickness $0.25 \mathrm{~mm})$. The operating $\mathrm{GC}$ conditions were the same conditions as described above. The mass spectrometer was operating in EI mode at $70 \mathrm{eV}$; ion source temperature, $200{ }^{\circ} \mathrm{C}$. Mass range was from $\mathrm{m} / \mathrm{z}$ 20 to 350 amu.

\section{Antitumor activity}

The antitumor activity was studied against P815 tumor cell line using colorimetric MTT (Methyl tetrazolium test) assay as described and modified by Tim Mosmann (Mosmann, 1983). P815 tumor cells were washed by centrifugation and incubated in 96-well microtiter plates (Bioster, Italy) at a density of $1.5 .10^{5}$ cells $/ \mathrm{mL}$ in $100 \mu \mathrm{L} /$ well of culture medium (DMEM supplemented with $5 \% \mathrm{FCS}$ and $1 \%$ of penicillin 
and streptomycin). Then, $100 \mu \mathrm{L}$ of culture medium containing the specified concentration of the tested compounds was added in each well. After exposure to serial concentrations of tested products for $48 \mathrm{~h}$ at $37{ }^{\circ} \mathrm{C}$ and $5 \% \mathrm{CO}_{2}, 100 \mu \mathrm{L}$ of medium were carefully aspirated from each well and replaced by $20 \mu \mathrm{L}$ of MTT solution $(5 \mathrm{mg} / \mathrm{mL}$ of PBS). After incubation in the same conditions for $4 \mathrm{~h}$, the plates are treated with solution of $\mathrm{HCl}$ / isopropanol (24:1) to dissolve the blue intracellular formazan product. One hour later, the plates are read on MicroelisA reader using two wavelengths $(540$ and $630 \mathrm{~nm}$ ). DMSO was used as negative control while methotrexate and vincristine as positive controls.

\section{Effect on human peripheral blood mononuclear cells (PBMC)}

This test was realised in order to evaluate the effect of our extracts on human normal cells using the MTT colorimetric assay described above.

To isolate the PBMC, blood samples were collected from healthy donors in heparinized tubes and peripheral blood mononuclear cells were isolated using standard Ficoll-hypaque density centrifugation. The interface lymphocytes were washed twice with phosphate-buffered solution (PBS). Essential oils, carvacrol and thymol were used at concentration of 0.5 $\%(\mathrm{v} / \mathrm{v})$. Vincristine was used at concentration of 0.5 $\mu \mathrm{g} / 100 \mu \mathrm{L}$.

\section{RESULTS AND DISCUSSION} Chemical composition of the essential oils and
extracts of thyme

The results obtained by GC/MS analysis of the essential oils and extracts are summarized in Tables 1,2, 3 , and 4. It is depicted in these tables that the chemical composition of Moroccan thyme extracts is characterised by its richness and its variety. Indeed, the number of products in the extract varies between a minimum of 71 and a maximum of 202 in the ethyl acetate extract of Thymus pallidus and Thymus zygis, respectively. The ethyl acetate extract is the most rich one with an average of 122 components followed by ethanol extract (109 components), petroleum ether extract (105 components) and the essential oil with an average of 88 products. Comparing species between them, we notice that the extracts of Thymus satureoides (chemotype Ts3) contain the most products with an average of 133 components by extract and those of Thymus pallidus contain in average 84 components per extract.

The chromatographic spectra of different extracts show also that the chemical composition varies from a species to another and from an extract to another. According to the chemical composition and particularly the nature of major products, which are often responsible for the biological activities, we can distribute the different species and chemotypes in five groups. Each group is represented by its chromatographic spectrum in Figure 1. The group 1, constituted by Tm, Tl, Tb1, Ta1 and $\mathrm{Ta} 2$, contains the carvacrol as the major component, group 2 represented by Ts 3 contains essentially the borneol, group 3 includes $\mathrm{Tz}$, Ts 2 and Tb2 which contain thymol/borneol, group 4 represented by $\mathrm{Tp}$ containing essentially borneol/thymol/paracymene and finally group 5 represented by Ts 1 with carvacrol/borneol as major components. On the other hand, with respect to these species, it is noteworthy that these major components are similar when going from an extract to another since only the proportions vary. Indeed, the percentages of the major components of Tb2 extracts (borneol/thymol) are $33.92 / 37.11,19.02 / 33.69,20.17 / 32.21$ and 18.69/37.18 for the essential oil, ethyl acetate, ethanol and petroleum ether extracts, respectively.

Comparing samples of the same species collected in different regions of Morocco, our results show that the chemical composition of thyme extract can vary according to the geographical localization. Thus, Thymus satureoides is represented by 3 chemotypes (chemotype with borneol (Ts3), chemotype with borneol/ thymol (Ts2) and chemotype with borneol/carvacrol (Ts1). While Thymus broussonettii is represented by 2 chemotypes (chemotype with carvacrol (Tb1) and chemotype with thymol/borneol (Tb2). Regarding Thymus algeriensis, the components are the same only the proportions vary. The chemical composition of thyme extracts, particularly that of essential oils, is known to be rich and diversified not only in Morocco (Tahiri, 1996; Benjilali et al., 1987; Richard et al., 1985) but also in other regions in the world (Stahl-Biskup, 1991; Raal et al., 2004). Carvacrol, thymol and borneol are the major products the most encountered in different extracts of Moroccan thyme. In other countries, the major products characterising thyme extracts can be different. In fact, in Estonia, the major components encountered are $E$-nerolidol, caryophyllene oxyde, myrcene, $(E)$-betacaryophyllene and germacrene-D (Raal et al., 2004). In northern California (USA), the major constituents of thyme are thymol, carvacrol, linalool, $\alpha$-terpineol and 1,8-cineole (Seung-Joo et al., 2005). Thymus praecox in the south of England can have as major product hedycaryol, linalol/lynalyl acetate or germacral-10, 4-dien-6-ol (Schmidt et al., 2004).

Many factors can be responsible for this variability in the chemical composition of thyme extracts. The most important are the climate, the soil, the harvest period and the method of preservation and extraction. Genetic factors (Echeverrigaray et al., 2001) and vegetative cycle (Hanci et al., 2003; Hudaib et al., 2002) can also influence this variability. However, in spite of this diversity, some components are curently encountered in all species whatever at variable amounts. It concerns monoterpenics phenols (thymol and 
carvacrol), its precursors monoterpenics hydrocarbures (p-cymene and $\gamma$-terpinene), oxygenate monoterpenes (borneol and linalol), terpinene-4-ol and 1,8-cineole (Stahl-Biskup, 1991). Our results are in agreement with such study but with a difference in the amount of the products and the nature of major components (Tables 1 , 2, 3 and 4).

\section{Antitumor activity}

The antitumor activity of thyme extracts was evaluated against P815 tumor cell line. These extracts include: the essential oils of one species of each group as well as the pure molecules, carvacrol and thymol. The results obtained are reported in Figure 2. It is shown in this figure that all products have an important dosedependant cytotoxic effect against P815 cell line. Indeed, at high concentration $(0.5 \% \mathrm{v} / \mathrm{v})$, the percentage of lysis is $100 \%$ for all the extracts. However, at medium and small concentrations, this effect depends on the nature of extracts. In fact, at $0.0625 \%(\mathrm{v} / \mathrm{v})$, the essential oil of $\mathrm{Ta} 1$ is more cytotoxic (100\% lysis) than that of Tb2 $60 \%$ lysis), Tp (22\% lysis), Ts1 (20\% lysis) and Ts 3 (18\% lysis). At very low concentration $(0.004 \% \mathrm{v} / \mathrm{v})$ of the essential oils, this order of sensitivity is also obtained. The concentration of each product to induce $50 \%$ of cytotoxicity is respectively $0.01 \%, 0.016 \%, 0.22 \%$, $0.225 \%$ and $0.24 \%$ for $\mathrm{Ta} 1, \mathrm{~Tb} 2, \mathrm{Tp}$, Ts 1 and $\mathrm{Ts} 3$. It appears from this analysis that essential oils containing a high amount of carvacrol are more cytotoxic than the others. Furthermore, when we have used the carvacrol alone (Figure 1), we found that this component is able to induce a very high cytotoxic activity with IC50 less than $0.004 \% \mathrm{v} / \mathrm{v}$. These results are in agreement with those of other authors who reported that the carvacrol has an important antitumor effect against tumor cell lines like Hep-2 (Stammati et al., 1999) and B16 (He et al., 1997). Interestingly, our results show that the group of essential oil rich in thymol is less cytotoxic than that rich in carvacrol (Figure 2). This observation is confirmed when we tested the effect of these pure compounds on P815 cell line survival. Indeed, the IC50 of thymol is $0.015 \%$. Our results are in agreement with those of (Salmenova et al., 2007) and (Braga et al., 2006) who reported that thymol has an antioxidant and antitumor effect. In the other hand, essential oil of thyme can have preventive effect opposite to cancer by the means of antioxidant properties of its components (Dursun et al., 1999; Lee; Shibamoto, 2002; Youdim; Deans, 2000).

\section{Effect of thyme essential oils, carvacrol and thymol against PBMC}

Knowing that one of the most problems of anticancer chemotherapy is its systemic toxicity, we tested our products against the human peripheral blood mononuclear cells (PBMC) in order to determine their effects against normal cells. The results obtained are represented in Figure 3. It is depicted in this figure that, except vincristine (positive control) and thymol which have cytotoxic effect on the PBMC, the other products show that at a concentration able to induce a cytotoxic activity against tumor cells (P815), no cytotoxicity was measured but, instead of that, a proliferative effect was observed against the normal PBMC (Figure 3). This proliferation was slight for essential oils of $\mathrm{Tb} 2, \mathrm{Tp}$, Ts1, Ts 3 and carvacrol (115-133\% of viability after $48 \mathrm{~h}$ of treatment), while that induced by the essential oil of Ta1 was important ( $200 \%$ of viability).

\section{CONCLUSION}

The aim of this study is to evaluate the chemical composition and antitumoral activity of extracts for eleven species and chemotypes of Moroccan thyme. Chemical analysis of essential oils and different extracts confirmed that Moroccan thyme is characterised by its richness and its diversity. In fact, the number and the nature of products vary from species to another and from extract to another with a minimum of 71 and a maximum of 202. The major compounds the most encountered in our extracts are the carvacrol, thymol, borneol and paracymene. Chemical composition of thyme extract can also vary according to the geographical localization. Thus, Thymus satureoides is represented by 3 chemotypes and Thymus broussonettii by 2 chemotypes.

Antitumoral activity of our extracts as well as that of two pure compounds (carvacrol and thymol) was evaluated against P815 tumor cell line. Our results show that Moroccan thyme extracts have an important cytotoxic effect and that the carvacrol is the most important cytotoxic product. Indeed, essential oils with high amount of carvacrol (group 1) are more cytotoxic. On the other hand, no cytotoxic effect of these essential oils was observed on the human normal cells but a proliferative one.

\section{ACKNOWLEDGMETS}

This work was supported by a grant from the CNRST, Rabat, Marocco (PROTARSIII, D61/07).

\section{REFERENCES}

Amaral FMM, Ribeiro MNS, Barbosa-Filho JM, Reis AS, Nascimento FRF, Macedo RO 2006. Plants and chemical constituents with giardicidal activity. Rev Bras Farmacogn 16(Supl.): 696-720.

Bellakhdar J 1996. La Pharmacopée Marocaine Traditionnelle. Ibiss Press, p. 358.

Benjilali B, Hammoumi M, Richard H 1987. Polymorphisme chimique des huiles essentielles de Thym du Maroc. Sci Aliment 7: 77-91.

Braga PC, Dalsasso M, Cilici M, Galastril L, Marceca MT, Guffanti EE 2006. Antioxidant potential of thymol 


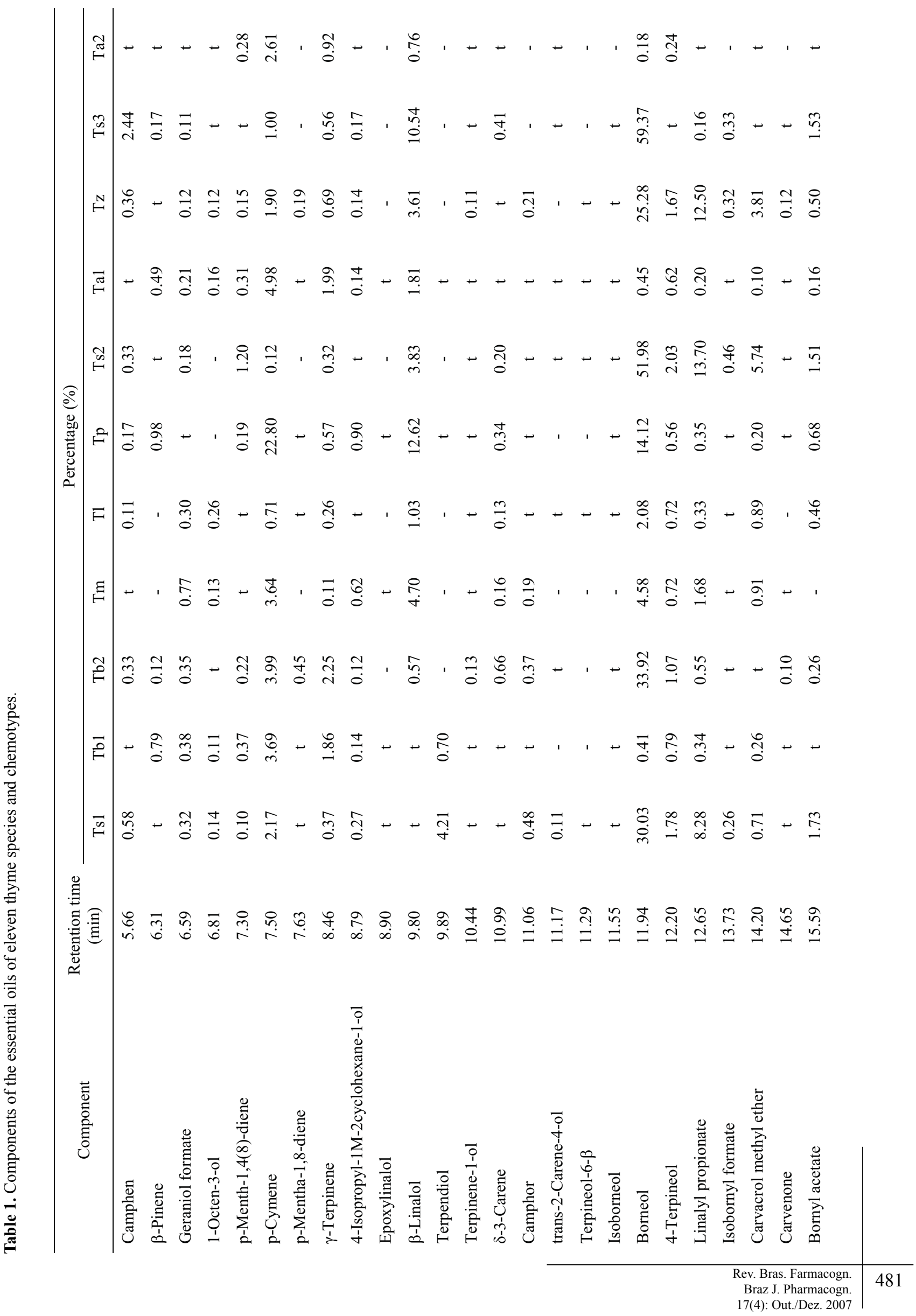




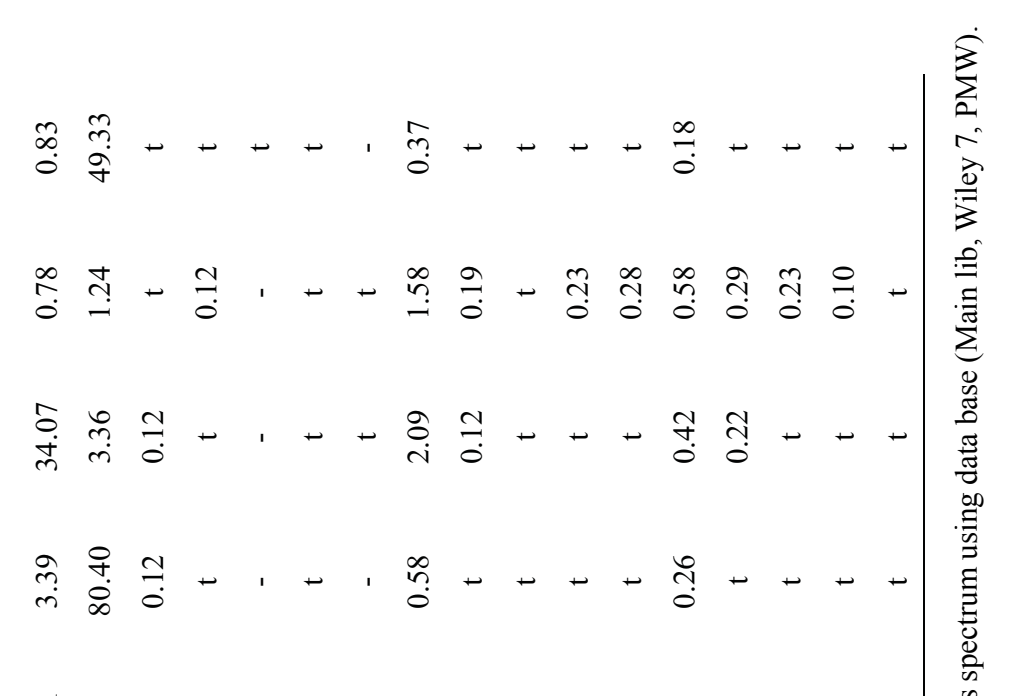

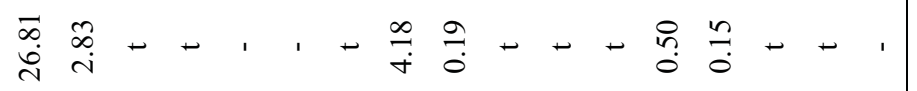

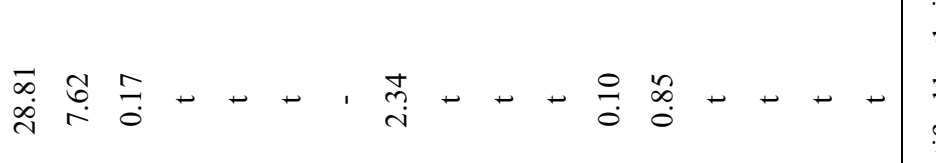

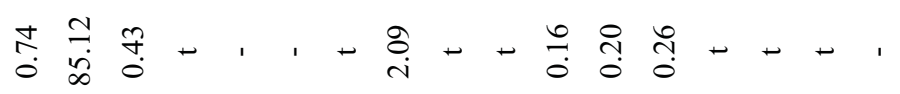

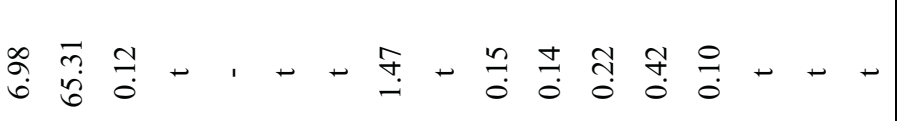

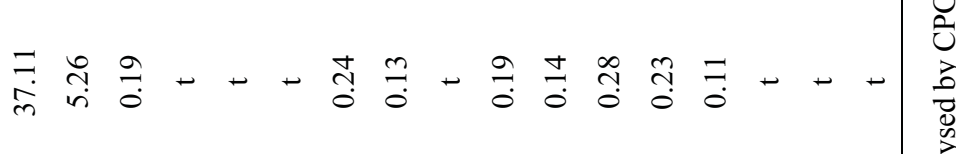

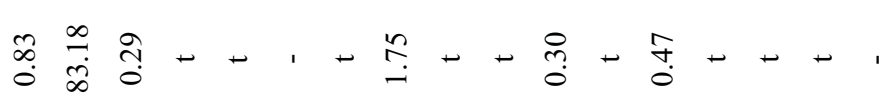

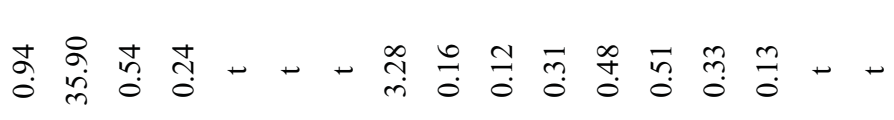

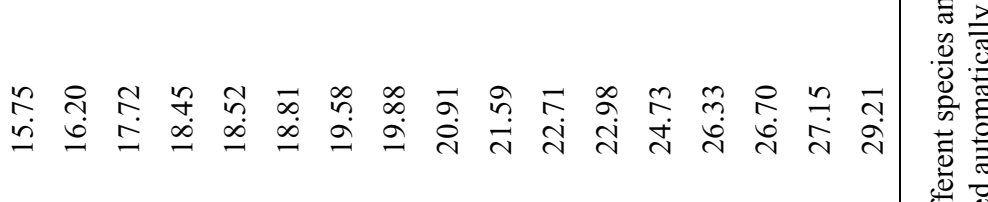

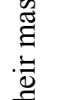

$$
\begin{aligned}
& \text { 官 } \\
& \begin{array}{l}
0 \\
0 \\
0 \\
0 \\
0 \\
0
\end{array} \\
& \text { 吾 }
\end{aligned}
$$

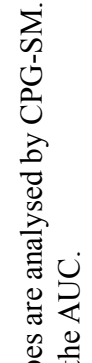

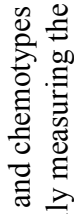

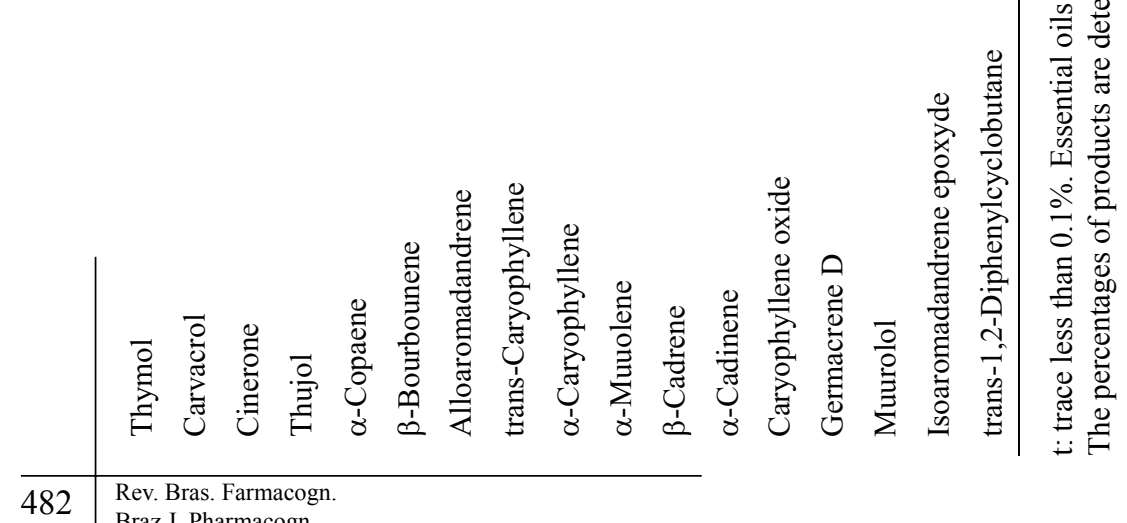




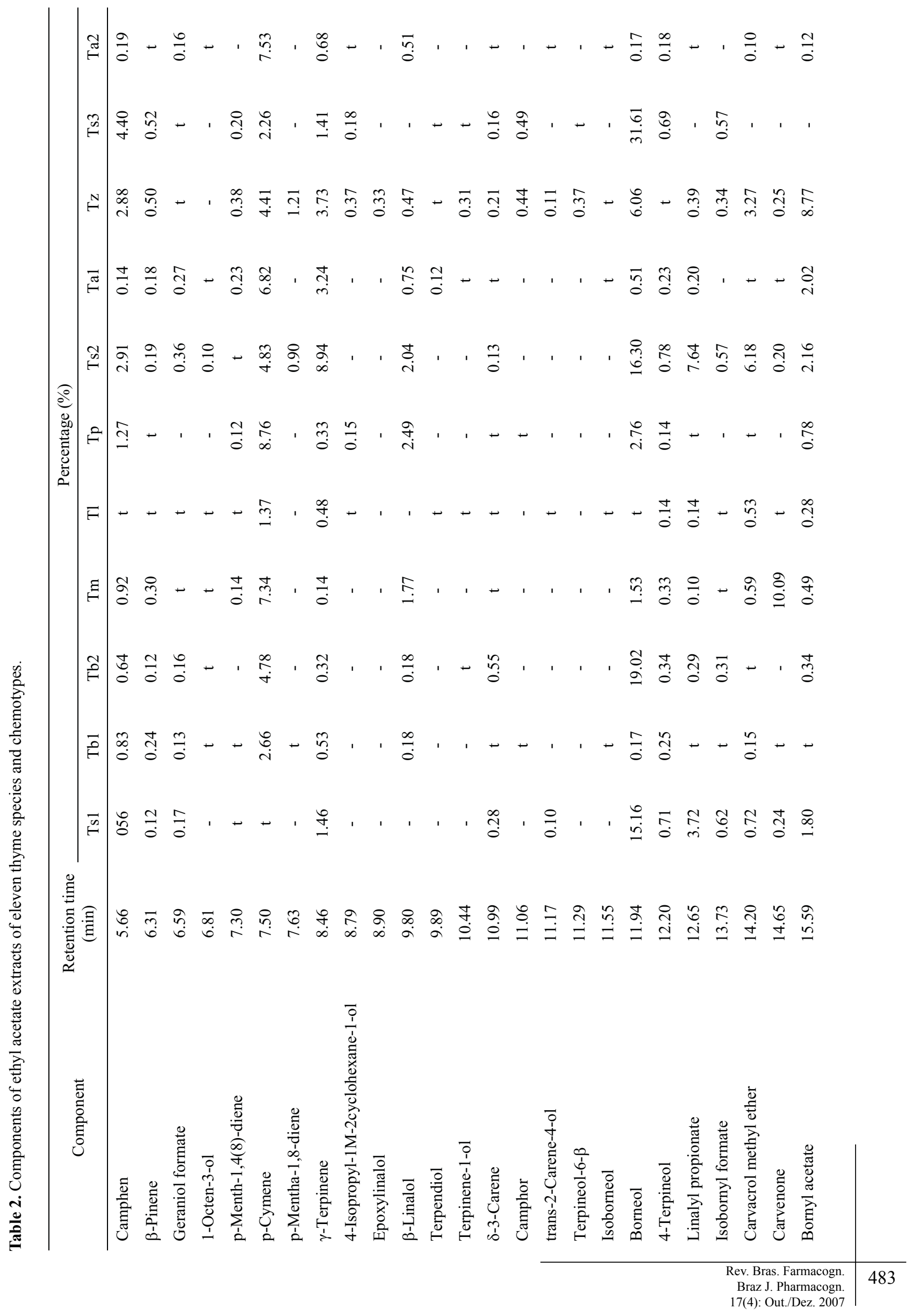




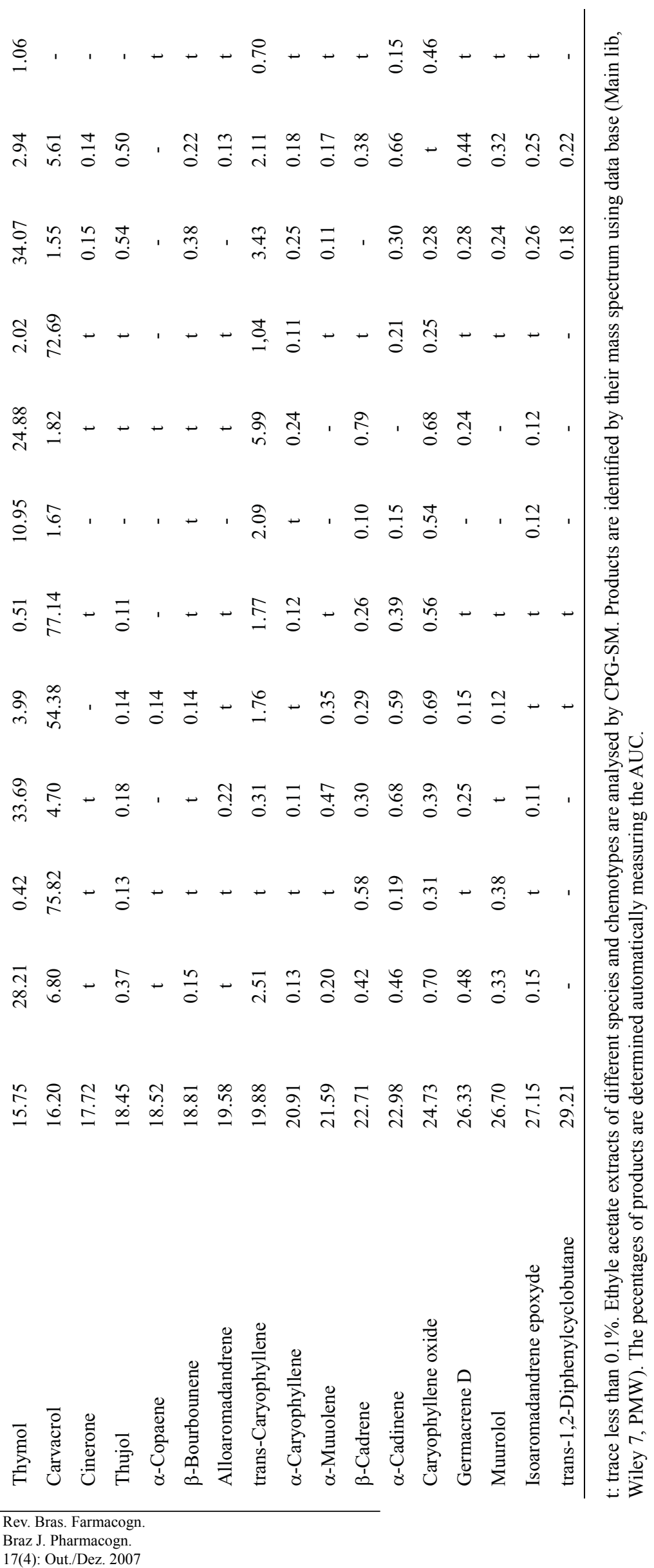




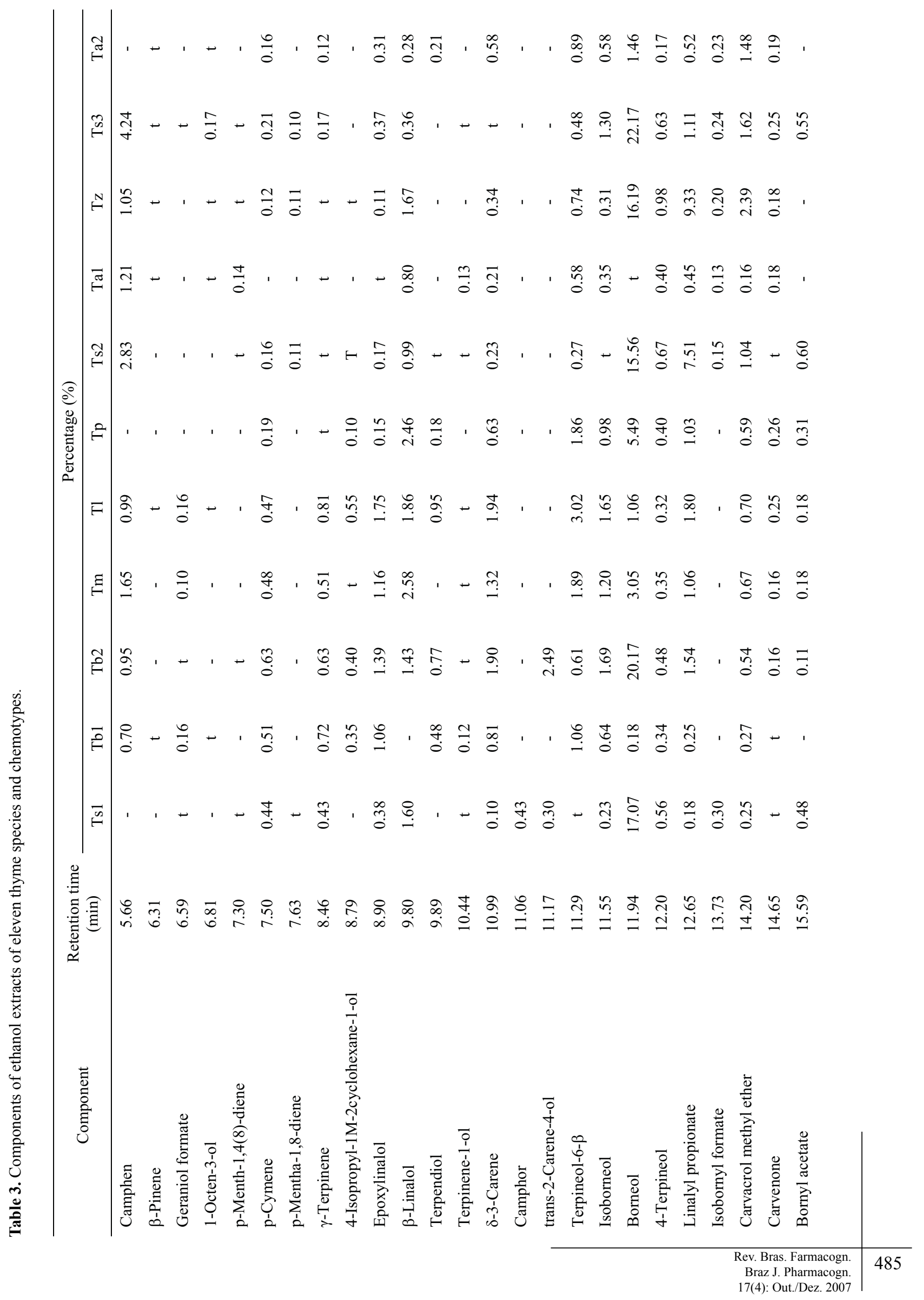


商苔, , , - +

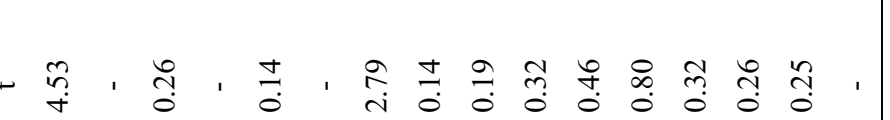

군

坣

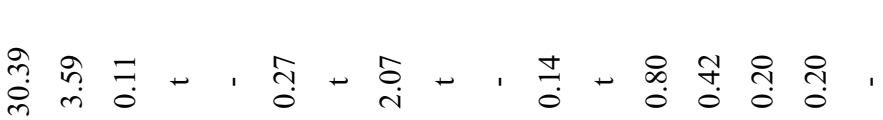

实舌

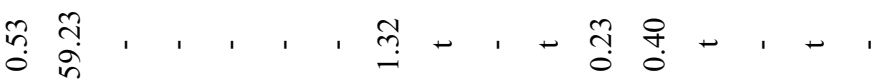

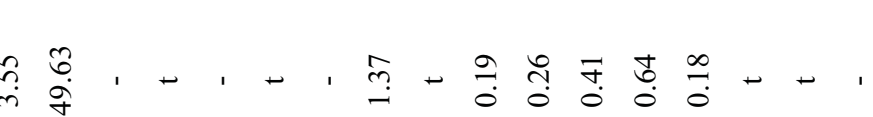

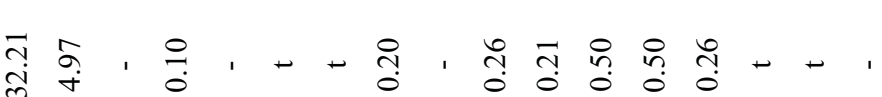

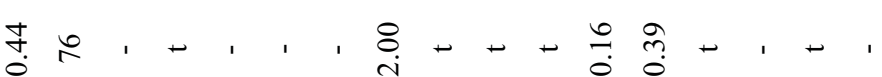

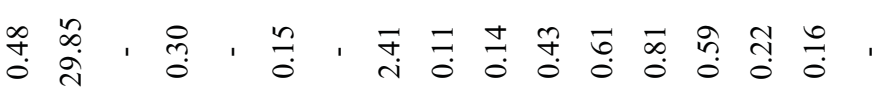

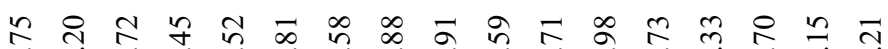

๓.

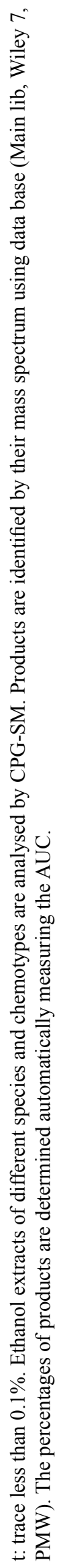




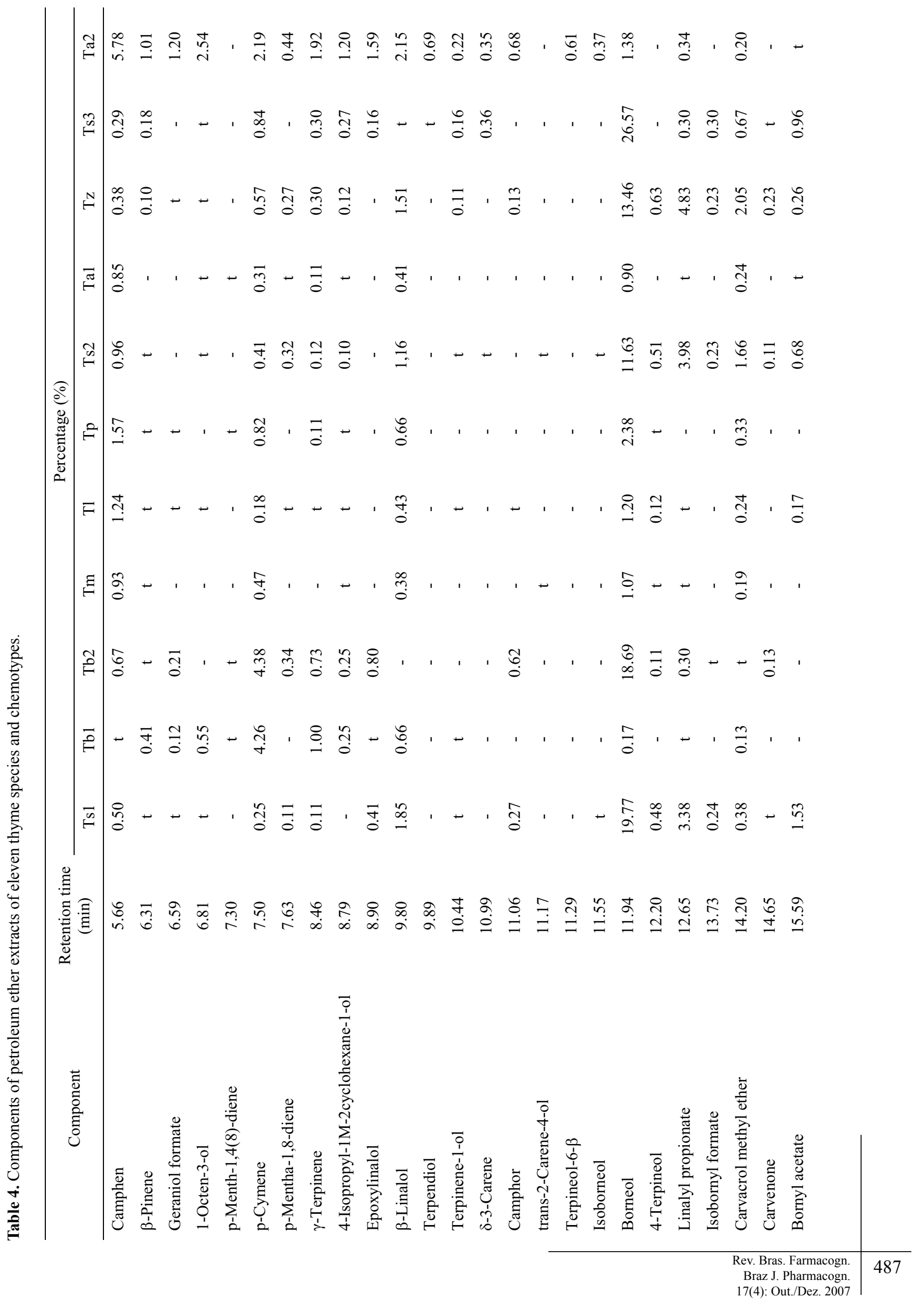




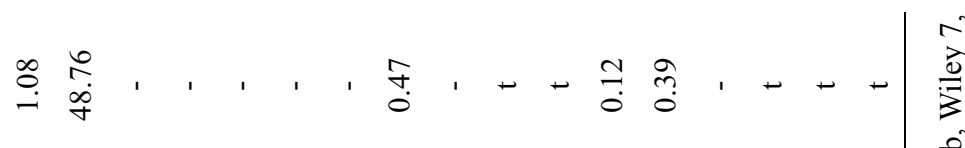

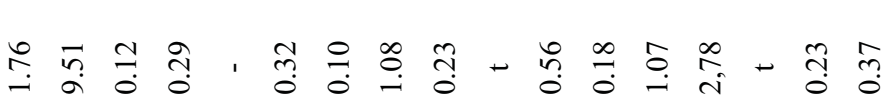

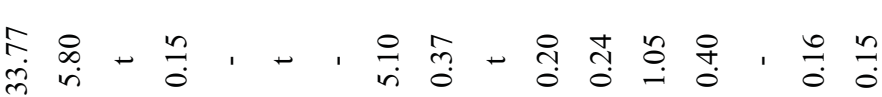

芦兽 , - , , -

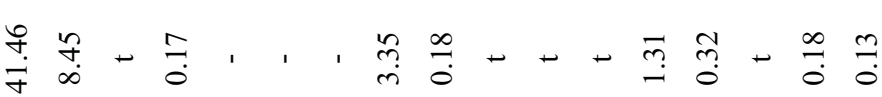

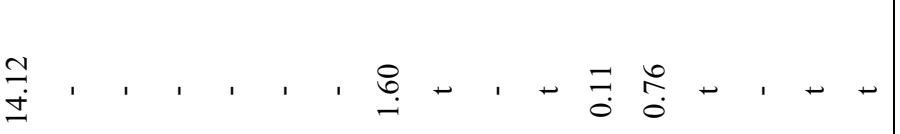

S.

చి

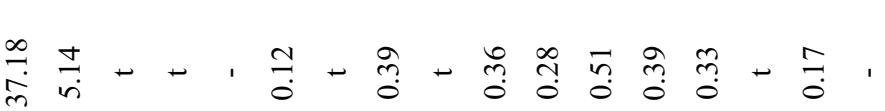

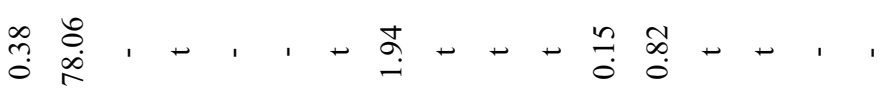

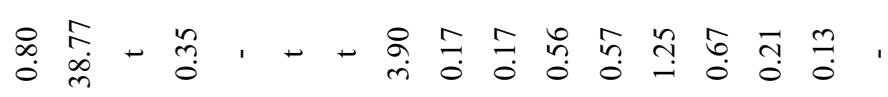

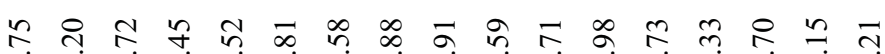

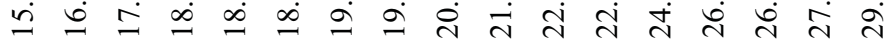



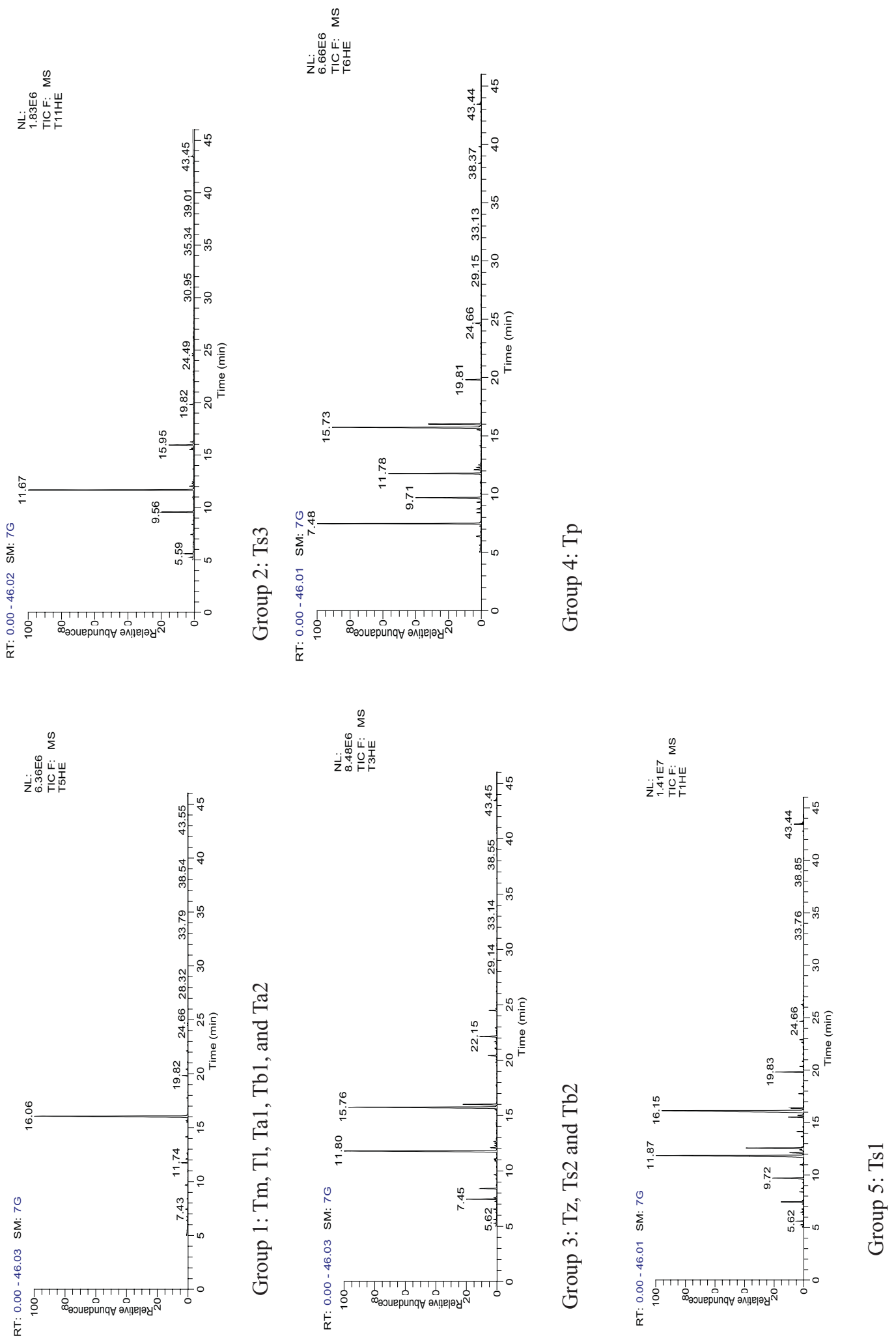

Different extracts were analysed by CPG-SM. According to the chemical composition and particularly the nature of major products, different species and chemotypes are distributed in five groups: group $1(\mathrm{Tm}, \mathrm{Tl}$, $\mathrm{Tb} 1, \mathrm{Ta} 1$ and Ta2), group 2 (Ts3), group 3 (Tz, Ts2 and Tb2), group $4(\mathrm{Tp})$, and group 5 (Ts1).

Figure 1. Spectra of different groups of extracts. 
cytotoxic effect of thyme essential oils, carvacrol and thymol against

P815 tumour cell line

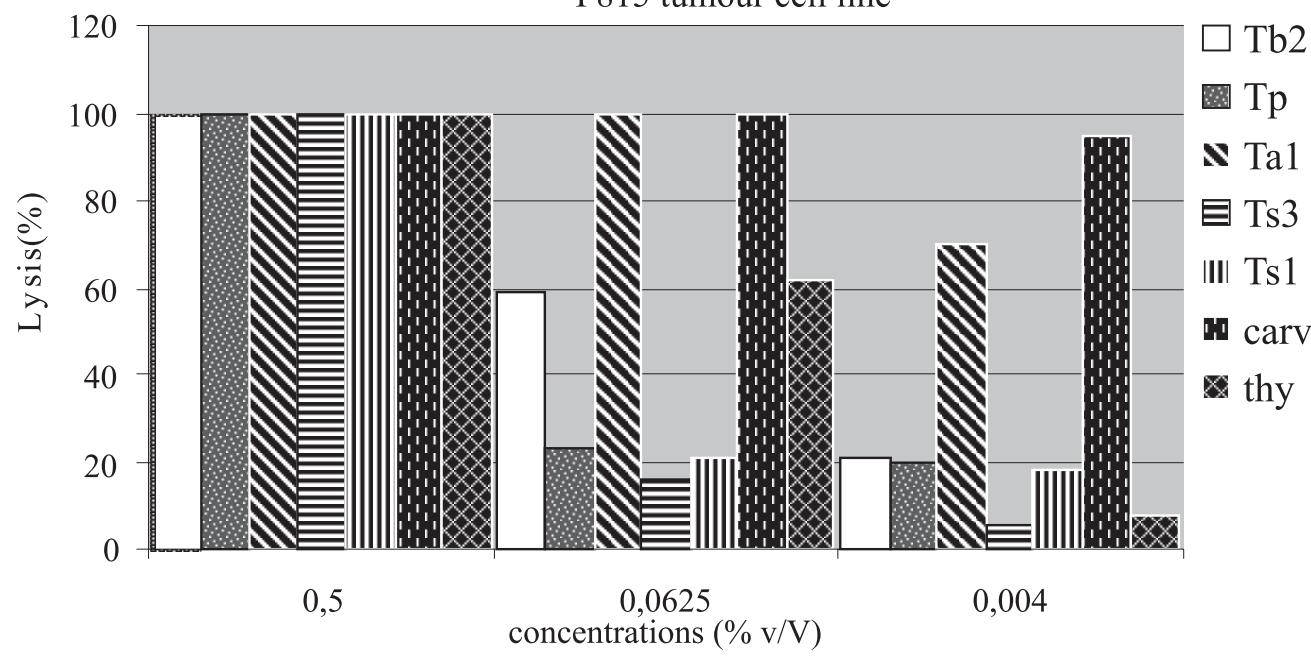

P815 tumor cells were washed by centrifugation and incubated in 96-well microtiter plates at a density of 1.5.10 $\mathrm{s}$ cells $/ \mathrm{mL}$ in $100 \mu \mathrm{L} /$ well of culture medium. Then, cells are stimulated by specified concentration $(0.004-0.5 \% \mathrm{v} / \mathrm{v})$ of the tested compounds (essential oils, carvacrol and thymol) for $48 \mathrm{~h}$ at $37{ }^{\circ} \mathrm{C}$ and $5 \%$ $\mathrm{CO}_{2}$. Lysis is determined using MTT assay as described in materials and methods.

Figure 2. Cytotoxic effect of thyme essentials oils, carvacrol and thymol against P815 tumor cell line.

Effect of thyme essential oils, carvacrol and thymol against the PBMC

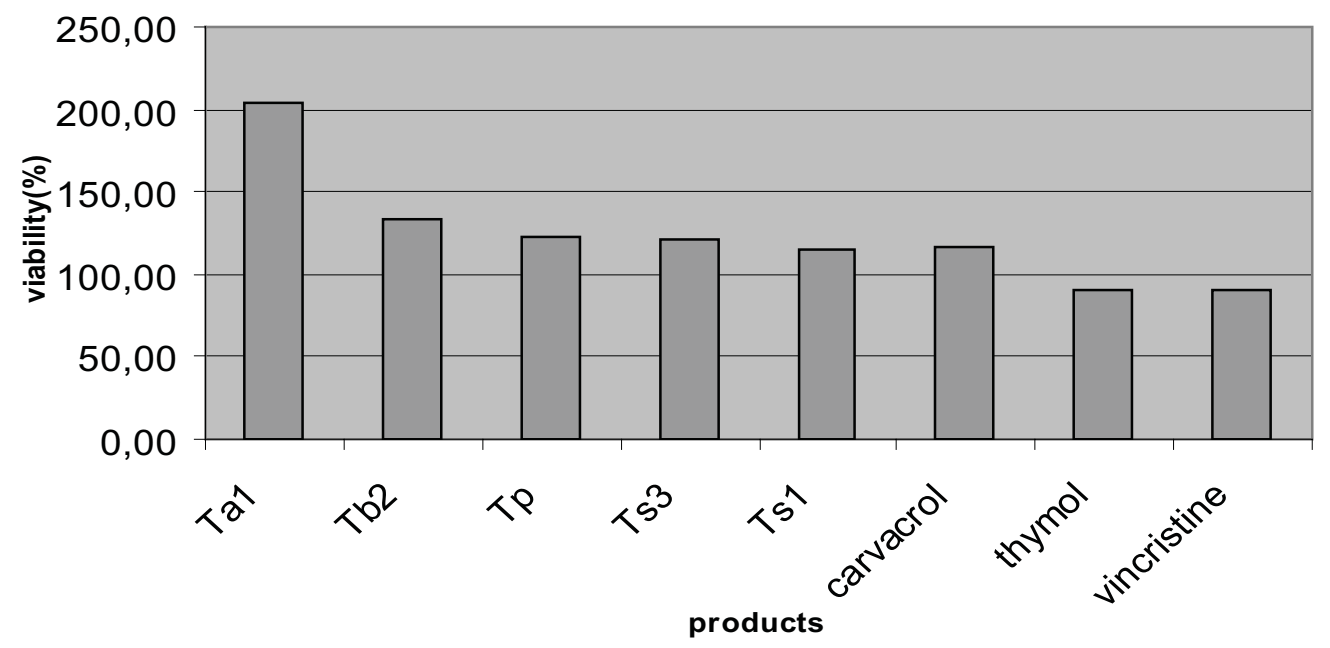

PBMC were prepared from human normal donors by Ficoll-hypaque density centrifugation. Cells $\left(2.10^{5} /\right.$ $\mathrm{mL}$ ) were incubated in 96-well microtiter plates in the presence of different products (essential oils, carvacrol and thymol) at a concentration of $0.5 \% \mathrm{v} / \mathrm{v}$, in final volume of $100 \mu \mathrm{L}$ of culture medium. Vincristine was used as positive control $(0.5 \mu \mathrm{g} / 100 \mu \mathrm{L})$. After $48 \mathrm{~h}$ incubation, viability was determined using MTT assay as described in materials and methods. Data are the mean of two different experiments.

Figure 3. Effect of thyme essential oils, carvacrol and thymol against human PBMC. 
determined by chemiluminescence inhibition in human neutrophils and cell-free systems. Pharmacology 76: 61-68.

Brandão MGL, Cosenza GP, Moreira RA, Monte-Mor RLM 2006. Medicinal plants and other botanical products from the Brazilian Official Pharmacopoeia. Rev Bras Farmacogn 16: 408-420.

Carlini EA, Rodrigues E, Mendes FR, Tabach R, Gianfratti B 2006. Treatment of drug dependence with Brazilian herbal medicines. Rev Bras Farmacogn 16: 690-695.

Dob T, Dahmane D, Benabdelkader T, Chelghoum C, 2006. Studies on the essential oil composition and antimicrobial activity of Thymus algeriensis Boiss. et Reut. Int J Aromath 16: 95-100.

Dursun N, Liman N, Ozyazgan I, Gunes I, Saraymen R 1999. Role of thymus oil in burn wound healing. Lett Appl Microbiol 29:130-135.

Echeverrigaray S, Agostini G, Atti-Serfini L, Paroul N, Pauletti GF, dos Santos AC 2001. Correlation between the chemical and genetic relationships among commercial thyme cultivars. J Agric Food Chem 49: 4220-4223.

Essawi T, Srour M 2000. Screening of some Palestinian medicinal plants for antibacterial activity. $J$ Ethnopharmacol 70: 343-349.

Hanci S, Sahin S, Yilmaz L 2003. Isolation of volatile oil from thyme (Thymbra spicata) by steam distillation. Nahrung 47: 252-255.

He L, Mo H, Hadisusilo S, Qureshi AA, Elson CE 1997. Isoprenoids suppress the growth of murine B16 melanomas in vitro and in vivo. $J$ Nutr 127: 668-674.

Hmamouchi M 2001. Les plantes médicinales et aromatiques marocaines. $2^{\mathrm{e}}$ édition.

Hudaib M, Speroni E, Di Pietra AM, Cavrini V 2002. GC/ MS evaluation of thyme (Thymus vulgaris L.) oil composition and variations during the vegetative cycle. J Pharm Biomed Anal 29: 691-700.

Ismaili $\mathrm{H}$, Tortora $\mathrm{S}$, Sosa $\mathrm{S}$, Fkih-Tetouani $\mathrm{S}$, Ilidrissi $\mathrm{A}$, Della Loggia R, Tubaro A, Aquino R 2001. Topical anti-inflammatory activity of Thymus willdenowii. $J$ Pharma Pharmacol 53: 1645-1652.

Ismaili $\mathrm{H}$, Sosa $\mathrm{S}$, Brkic $\mathrm{D}$, Fkih-Tetouani $\mathrm{S}$, Ilidrissi $\mathrm{A}$, Touati D, Aquino R, Tubaro A 2002. Topical antiinflammatory activity of extracts and compounds from Thymus broussonettii. J Pharma Pharmacol 54: 1137-1140.

Ismaili $\mathrm{H}$, Milella L, Fkih-Tetouani S, Ilidrissi A, Camporese A, Sosa S, Altinier G, Della Loggia Aquino R 2004. In vivo topical anti-inflammatory and in vitro antioxidant activities of two extracts of Thymus satureioides leaves. J Ethnopharmacol 91: 31-36.

Lee KG, Shibamoto T 2002. Determination of antioxidant potential of volatile extracts isolated from various herbs and spices. J Agric Food Chem 50: 4947-4952.

Meister A, Bernhardt G, Christoffel V, Buschauer A 1999. Antispasmodic activity of Thymus vulgaris extract on the isolated guinea-pig trachea: discrimination between drug and ethanol effects. Planta Med 65: 512-516.

Mosmann T, 1983. Rapid colorimetric assay for cellular growth and survival: Application to proliferation and cytotoxic assay. J Immunol Methods 65: 55-63.

Raal A, Paaver U, Arak E, Orav A 2004. Content and composition of the essential oil of Thymus serpyllum L. growing wild in Estonia. Medicina 40: 795-800.

Richard H, Benjilali B, Banquour N, Baritaux O 1985. Etude de diverses huiles essentielles de thym du Maroc. Lebensm-Wiss Technol 18: 105-110.

Salmenova D, Horvathora E, Sramkova M, Marsalkova L 2007. DNA protective effects of two components of essential plant oil, carvacrol and thymol on mammalian cells cultured in vitro. Neoplasma 54: 108-112

Schmidt A, Bischof-Deichnik C, Stahl-Biskup E 2004. Essential oil polymorphism of Thymus praecox subsp. arcticus on the British Isles. Bioch Syst Ecol 32: 409-421.

Seung-Joo L, Katumi U, Takayuki S, Kwang-Geun L 2005. Identification of volatile components in basil (Ocimum basilicum L.) and thyme leaves (Thymus vulgaris L.) and their antioxidant properties. J Food Chem 91: 131-137.

Sijelmassi A 1993. Les plantes médicinales du Maroc. Editions Le Fennec, Casablanca, 286 pp.

Soliman KM, Badeaa RI 2002. Effect of oil extracted from some medicinal plants on different mycotoxigenic fungi. Food Chem Toxicol 40: 1669-1675.

Stahl-Biskup E 1991.The chemical composition of Thymus oils: review of the literature 1960-1989. J Essent Oil Res 3: 61-82.

Stammati A, Bonsi P, Zucco F, Moezelaar H-L, Alakomi von Wright A 1999. Toxicity of selected plant volatils in microbial and mammalian short-term. Food Chem Toxicol 37: 813-823.

Tahiri B 1996. Contribution à l'étude biosystématique et chimique du genre Thymus L. (Labiatae) au Maroc. Thèse de Doctorat de 3eme cycle, Faculté des sciences Rabat.

Tepe B, Sokmen M, Akpulat HA, Daferera D, Polissiou M, Sokmen A 2005. Antioxidative activity of the essential oils of Thymus sipyleus subsp.sipyleus var. sipyleus and Thymus sipyleus subsp. sipyleus var. rosulans. J Food Eng 66: 447-454.

Vuorelaa P, Leinonenb M, Saikkuc P, Tammelaa P, Rauhad JP, Wennberge T, Vuorela H 2004. Natural products in the process of finding new drug candidates. Curr Med Chem 11: 1375-1389

Youdim KA, Deans SG 2000. Effect of thyme oil and thymol dietary supplementation on the antioxidant status and fatty acid composition of the ageing rat brain. $\mathrm{Br} J$ Nutr 83: 87-93. 